\title{
The Effect of Self-Stigma and Perceived Social Support
}

\section{Towards Help-Seeking on Students}

\author{
Lucky Hardinugraha $^{a}$, Anita Zulkaida ${ }^{b}$ \\ ${ }^{a}$ hardinugrahalucky@gmail.com \\ b zulkaida04@staff.gunadarma.ac.id \\ ${ }^{\text {a b }}$ Gunadarma University, J1. Margonda Raya 100, Depok, 16424, Indonesia
}

\begin{abstract}
Currently, many people are experiencing psychological problems, including students, and the number is increasing. However, there are still many who are reluctant to seek professional help. This can be caused by internal factors such as self-stigma and external factors such as social support. This study aims to examine the effect of self-stigma and perceived social support on help-seeking behavior from professionals. The research participants were 436 undergraduate students at universities in the Greater Jakarta area, Indonesia, and were obtained using the snowball sampling technique. The measuring instruments used in this research are Attitudes Toward Seeking Professional Psychological Help-Short Form (ATSPPHSF), Self-Stigma of Seeking Help (SSOSH), and Multidimensional Scale of Perceived Social Support (MSOPSS). The analysis was performed using a multiple linear regression test. The results show that together, self-stigma and perceived social support significantly affect help-seeking, and the magnitude of the impact is $26.8 \%$. As for the influence of each variable, self-stigma has a very significant effect on help-seeking, while perceived social support does not have a significant impact on help-seeking. This means that participants, efforts to seek help when experiencing psychological problems, are more influenced by how stigmatized they are. The existence of stigma against themselves will prevent participants from seeking professional help when experiencing psychological problems.
\end{abstract}

Keywords: Help-Seeking; Self-Stigma; Perceived Social Support; College Students

\section{Introduction}

A student is someone who is in the process of gaining knowledge or studying and is registered to be undergoing education at one of the forms of higher education consisting of academics, polytechnics, high schools, institutes, and universities (Hartaji, 2012). Continuing to study in college is usually considered a good and positive experience because there are many new opportunities in it. However, there are often stressful conditions for students. This can happen because generally, students are at the age of crossing between adolescents and adults where they have to adapt to the demands of new situations such as living conditions, teaching styles that are different from previous schools, unique lifestyles, or their responsibilities (Bouteyre, Maurel, et al. \& Bernaud, 2007). In addition, for some students, entering college can be their first experience away from family in a long time. Various changes and demands experienced by students can cause high stress or pressure, which is very likely to cause psychological problems or mental-emotional disorders.

Several studies show that many new students experience mental-emotional disorders. The mental-emotional disorder is a condition that indicates that the individual experiences an emotional change that can develop into a pathological state (Idaiani, Suhardi, \& Kristanto, 2009). The prevalence of mental-emotional disorders that occur in first-year students is high, at $12 \%$ to $50 \%$ (Blanco, Okuda, Wright, Hasin, Grant, Liu, \& Olfson, 2008; Hunt \& Eisenberg, 2010; Verger, Guagliardo, Gilbert, Rouillon, \& Kovess-Masfety, 2010). The findings show that as many as $30 \%$ of new students experience distress psychological, such as anxiety and depression (Adlaf, 
Gliksman, Demers, \& Newton-Taylor, 2001). The high prevalence of mental-emotional disorders in new students also occurs in Indonesia. Research at one university in Jakarta found that $12.7 \%$ of students experienced mental and emotional disorders (Vidiawati, Iskandar, \& Agustian, 2018). Another study conducted at Udayana University showed that as many as $29.31 \%$ of new students experienced clinical symptoms that indicated severe depression (Karin, 2017).

The government has tried to provide places of service to deal with psychological problems, such as in local public health centers mental-emotional or regional general hospitals. The cost of mental health care or treatment can also be claimed with BPJS Health so that people do not need to think about the high cost of mental health treatment. In addition to services from the government, many psychological institutions in Indonesia can provide counseling services with psychologists or psychiatrists such as Ibunda.id, Riliv, Bureau of Dynamic Psychology, and APDC Indonesia. Socialization is also pretty much done through electronic media or social media. However, healing can also be caused by the individual himself, namely the individual's efforts to seek help, especially from professionals, or often referred to as help-seeking.

According to Rickwood et al. (2005), help-seeking is the behavior of seeking help from others in terms of understanding, advice, information, care, and general support in response to a problem or troublesome experience. Meanwhile, Gourash (in Price \& Dalgeish, 2013) defines help-seeking as the behavior of communicating problems to get support, advice, or assistance in times of distress.

Help, according to Rickwood et al. (2005) can be searched from various sources that vary based on the level of formality. Informal help-seeking stems from informal social relationships, such as friends and family. Formal help-seeking comes from professional help sources, i.e., professionals who have a recognized role and appropriate training in providing assistance and advice, such as medical and mental health professionals. This process of seeking psychological help begins with being aware of the symptoms and having personal problems that may require intervention. This awareness and problem solving must then be articulated or expressed in words that others can understand and comfortable for the individual seeking help to define. Sources of help must also be available and accessible. Finally, help seekers must be willing and able to express their feelings to the source (Rickwood, 2005). However, seeking professional help is often not done due to several obstacles, ranging from internal and external causes.

One of the main reasons people with a predisposition to mental disorders avoid diagnosis or treatment is the stigma associated with mental disorders. The US Surgeon General's report on mental health states that stigma prevents people with mental disorders from acknowledging their illness, seeking help, and disclosing this to others (Satcher, 2000). Stigma also prevents people from seeking help because they want to avoid labeling (Cooper, Corrigan, \& Watson, 2003). Not infrequently, this stigma can come from oneself or is commonly referred to as self-stigma. Self-stigma is a condition when a person justifies stereotypes about himself (Corrigan \& Rao, 2013). The International Federation of Anti-Leprosy Associations or ILEP (2011) defines stigma as a negative response to human differences. As for self-stigma or internalized stigma, when someone has been stigmatized or has felt stigmatized for a long time, they start to believe what other people say and think about them. As a result, they lose self-respect and dignity, and/or fear, shame, hopelessness, and guilt. People with self-stigma consciously or unconsciously accept reduced expectations and begin to behave as expected by others.

In addition to internal factors, help-seeking behavior is influenced by external factors, one of which is perceived social support. Perceived social support is one of two types of social support (perceived social support and received social support) (Young, 2006). According to Young (2006), perceived social support is the degree to which a person believes that the people in their life are available to help them. Meanwhile, according to Srivastava and Angelo (2009), perceived social support is defined as a person's belief that other people will be available to provide help and comfort if needed. People with high perceived social support will tend to do more help-seeking behavior when compared to people who have low perceived social support. According to Weiss (in Russell, Cutrona, Rose, \& Yurko, 1984), there are six aspects needed for a person to feel socially supported, namely guidance, reliable colleagues, belief in self-worth (reassurance of worth), attachment (guidance), social integration and opportunities to provide care (opportunity of nurturance). 
Research on help-seeking has been pretty much done outside. The urgency of research on help-seeking in students can be seen based on related studies in various countries that show low help-seeking behavior in students. Research conducted by ACHA-NCHA (2008) showed that only 24\% of American college students with depression received and did treatment. Choi's (2012) research in South Korea indicates that there is only $10 \%$ of counseling services for most campuses in South Korea. However, as far as the search has been carried out, there have not been many studies in Indonesia that discuss help-seeking, especially for students. Moreover, there have not been many studies that have looked at the influence of both internal and external factors on helpseeking in students. Several studies have reported that self-stigma is associated with help-seeking and is a significant predictor of psychological help-seeking (Salaheddin \& Mason, 2016; Damghanian \& Alijanzadeh, 2018; Topkaya, 2014; Teh, King, Watson, \& Lio, 2014). Research on perceived social support also influence help-seeking behavior (Orji \& Abikoye, 2019; Koydemir, 2010; Cebi, 2009; Morgan et al., 2005). However, as far as the search has been carried out, no research has been found that looks at the effect of self-stigma and perceived social support on help-seeking behavior in students. Therefore, this study specifically aims to determine the impact of self-stigma and perceived social support on help-seeking behavior in students.

\section{Research Methods}

\subsection{Participants}

The participants in this study were 436 undergraduate students at universities in the Greater Jakarta area, Indonesia, which were obtained using the snowball sampling technique. Johnson (2014) states that snowball sampling is a non-probability method of selecting survey samples which are usually used to search for rare or hard-to-find populations, and there is the identification of a sample of participants with specific characteristics and requests for references to other potential participants who are potentially eligible or who are believed to have these characteristics.

\subsection{Method}

This research is a quantitative study. Data was collected using a questionnaire consisting of an identity section and a scale to measure help-seeking, self-stigma, and perceived social support. The distribution and filling of the questionnaires were done online via Google Form.

\subsection{Research Instruments}

The scale used to measure help-seeking in this study is the Attitudes Toward Seeking Professional Psychological Help-Short Form (ATSPPH-SF) developed by Fischer and Farina (1995). This scale is unidimensional, with a total of 10 items. This scale uses four alternative answers based on participants' agreement with each statement, answering from Disagree to Agree. According to Azwar (2014), the item selection criteria are based on item-total correlation of at least 0.25 for differentiating power which is considered satisfactory. After analyzing the data, four of the 10 items were obtained with the item-total correlation coefficient below 0.25 . The item-total correlation of the six good items moved from 0.296 to 0.502 . Reliability test by looking at the Cronbach's Alpha coefficient value and obtained a reliability coefficient of 0.669 for the six good items.

While the scale used to measure self-stigma in this study is the Self-Stigma of Seeking Help (SSOSH), compiled by Vogel, Wade, and Hackler (2006). This scale is unidimensional, with a total of 10 items. This scale uses five alternative answers based on participants' agreement with each statement, with answer choices from Strongly Disagree to Strongly Agree. The item-total correlation of 10 good items moves from 0.300 to 0.584. 
Reliability test by looking at the Cronbach Alpha coefficient value and obtained a reliability coefficient of 0.768 for 10 good items.

To measure perceived social support, this study uses the Multidimensional Scale of Perceived Social Support (MSOPSS) compiled by Zimet, Dahlem, Zimet, and Farley (1988). This scale is multidimensional, with a total of 12 items divided into three dimensions, namely significant other, family, and friends. This scale uses seven alternative answers based on participants' agreement with each statement, with answer choices from Strongly Disagree to Strongly Agree. Item-total correlation of the four good items from the significant other dimension moves from 0.747 to 0.873 . The good item-total correlation of the four items from the family dimension moves from 0.721 to 0.852 . The item-total correlation of the four good items from the friends' dimension moves from 0.677 to 0.733 . Reliability test by looking at the Cronbach's Alpha coefficient and obtained a reliability coefficient of 0.903 for the significant other dimension, 0.901 for the family dimension, and 0.859 for the friends' dimension.

\subsection{Research Procedure}

Before filling out the questionnaire, participants first filled out the willingness to be involved in the research. After filling in the willingness to become a research participant, fill in the identity on the questionnaire and continue by filling in the help-seeking, self-stigma, and perceived social support scales. The results of filling out the scale by participants were then analyzed with multiple regression statistical tests.

\section{Results}

Based on 436 data obtained, 135 male participants (30.9\%) and 301 female participants (69\%). The researcher tested the effect of self-stigma and perceived social support on help-seeking by using multiple regression with the help of the SPSS for Windows version 25 program. After analyzing the regression test, it was found that self-stigma and perceived social support together gave a powerful influence. Significant to helpseeking, and the magnitude of the effect is $26.8 \%$. For the impact of each variable, the results show a very significant effect of self-stigma on help-seeking. Still, there is no significant effect of perceived social support on help-seeking.

Table 1. Model Summary

\begin{tabular}{lr|c|r|r} 
Model & $\mathrm{R}$ & $\mathrm{R}$ Square & Adjusted R Square & \multicolumn{2}{c}{ Std. Error of the Estimate } \\
\hline 1 & $.518^{\mathrm{a}}$ & .268 & .265 & 2872 \\
\hline a. Predictors: (Constant), PerceivedSocialSupport, SelfStigma & &
\end{tabular}

Table 2. Anova Result

\begin{tabular}{llr|r|r|r|r}
\hline \multicolumn{1}{l}{ Model } & Sum of Squares & df & Mean Square & F & \multicolumn{1}{c}{ Sig. } \\
\hline \multirow{2}{*}{1} & 1309,673 & 2 & 654,836 & 79,366 & $000^{\mathrm{b}}$ \\
\cline { 2 - 7 } & Regression & 3572,593 & 433 & 8,251 & & \\
\cline { 2 - 7 } & Residual & 4882,266 & 435 & & & \\
\hline
\end{tabular}

a. Dependent Variable: HelpSeeking

b. Predictors: (Constant), PerceivedSocialSupport, SelfStigma 


\begin{tabular}{|c|c|c|c|c|c|c|}
\hline \multirow{2}{*}{\multicolumn{2}{|c|}{ Model }} & \multicolumn{2}{|c|}{$\begin{array}{l}\text { Unstandardized } \\
\text { Coefficients }\end{array}$} & \multirow{2}{*}{$\begin{array}{c}\text { Standardized } \\
\text { Coefficients } \\
\text { Beta }\end{array}$} & \multirow[b]{2}{*}{$\mathrm{t}$} & \multirow[b]{2}{*}{ Sig. } \\
\hline & & B & Std. Error & & & \\
\hline \multirow[t]{3}{*}{1} & (Constant) & 19,928 & .887 & & 22,459 & .000 \\
\hline & SelfStigma & -.326 & .026 & -.518 & $-12,573$ & .000 \\
\hline & PerceivedSocialSupport & .001 & .010 & .006 & .148 & .882 \\
\hline
\end{tabular}

\section{Discussion}

This study aims to examine the effect of self-stigma and perceived social support on student help-seeking. Based on the results of multiple regression tests that have been carried out, it is known that self-stigma and perceived social support together have a significant effect on help-seeking. However, based on the influence of each variable, it is known that only self-stigma has a very significant impact. At the same time, the effect of perceived social support on help-seeking is not significant. These results indicate that in participants, efforts to seek professional help when experiencing psychological problems are more influenced by how stigmatized they are. This means that the more individuals internalize stereotypes about themselves from others, the lower their tendency to seek help. These results are consistent with the results of previous studies (Hackler, Vogel, \& Wade, 2010; Topkaya, 2014; Salaheddin \& Mason, 2016; and Damghanian \& Alijanzadeh, 2018), which state that self-stigma influences help-seeking. Self-stigma is a significant factor that prevents depression or anxiety from seeking appropriate help for mental health problems (Damghanian \& Alijanzadeh, 2018). Meanwhile, the variable perceived social support does not have a significant effect on help-seeking. This is similar to the research conducted by $\mathrm{Ng}$, Jin, Ho, Chua, Fones, and Lim (2008) that there is no effect of perceived social support on help-seeking. The ineffectiveness of perceived social support on help-seeking for students could be due to the low perception of the availability of people around them to assist.

Other results show that the effect of self-stigma and perceived social support together on help-seeking is $26.8 \%$, while other factors influence $73.2 \%$. This indicates that other factors can affect help-seeking. Other factors that may influence help-seeking are personal beliefs about the need to ask for help, gender norms regarding help-seeking, personal experience with help-seeking, distance to the source of help, availability of services, cost of services, etc. Barker, 2007).

\section{Conclusions and Suggestions}

Based on the research conducted, it can be concluded that self-stigma and perceived social support have a significant effect on help-seeking. Partially, there is a very significant self-stigma effect on help-seeking. The higher the self-stigma of the participants, the lower the effort to seek professional help. However, perceived social support does not have a significant effect on help-seeking.

This research is realized that it is still far from perfection, and there are still shortcomings. Based on the results of the study that has been done, some suggestions can be put forward as follows:

- Researchers suggest that students can use the results of this study as additional insight and understanding to improve help-seeking, namely by not accepting and justifying the stereotypes given by others.

- For further researchers interested in researching the same theme, it is recommended to be more evenly distributed in determining respondents. The researcher also suggests looking at the effect of self-stigma and perceived social support and considering other factors that may have more influence on help-seeking. 


\section{References}

Adlaf, E. M., Gliksman, L., Demers, A., \& Newton-Taylor, B. (2001). The prevalence of elevated psychological distress among canadian undergraduates: Findings from the 1998 Canadian campus survey. Journal of the American College Health Association, 50(2), 6772.

American College Health Association-National College Health Assessment Spring 2008 Reference Group Data Report (Abridged): The American College Health Association. (2009). Journal of American College Health, 57(5), 477-488.

Azwar, S. (2014). Meode penelitian. Yogyakarta: Pustaka Pelajar.

Barker, G. (2007). Adolescents, social support, and help-seeking behaviour: An international literature review and programme consultation with recommendations for action. World Health Organization.

Blanco, C., Okuda, M., Wright, C., Hasin, D. S., Grant, B. F., Liu, S. M., \& Olfson, M. (2008). Mental health of college students and their non-college-attending peers: Results from the national epidemiologic study on alcohol and related conditions. Archives of General Psychiatry, 65(12), 1429-1437.

Bouteyre, E., Maurel, M., \& Bernaud, J. (2007). Daily hassles and depressive symptoms among first year psychology students in France: the role of coping and social support. Stress and Health, 23(2).

Brakel, W. V., Voorend, C., Ebenso, B., Cross, H., \& Augustine, V. (2011). The guidelines to reduce stigma: Guide 1. London/Amsterdam: The International Federation of Anti-Leprosy Associations (ILEP) and the Netherlands Leprosy Relief (NLR).

Cebi, E. (2009). University students' attitudes toward seeking psychological help: effects of perceived social support, psychological distress, prior help-seeking experience, and gender. Middle East Technical University. Scribbr. https://citeseerx.ist.psu.edu/viewdoc/download?doi=10.1.1.633.8302\&rep=rep1\&type=pdf

Choi, Y. M. (2012). Review of current conditions of university and college counseling centers in Korea and the United States. Journal of Human Understanding and Counseling, 33, 21-36.

Cooper, A., Corrigan, P., \& Watson, A. (2003). Mental illness stigma and care seeking. The Journal of Nervous and Mental Disease.191(5), 339-341.

Corrigan, P. W. \& Rao, D. (2012). On the self-stigma of mental illness: Stages, disclosure, and strategies for change. Can J Psychiatry, 57 (8), 464-469.

Damghanian, M. \& Alijanzadeh, M. (2018). Theory of planned behavior, self-stigma, and perceived barriers explains the behavior of seeking mental health services for people at risk of affective disorders. Social Health and Behavior. 1, 54-61.

Hackler, A. H., Vogel, D. L., \& Wade, N. G. (2010). Attitudes towards seeking professional help for an eating disorder: The role of stigma and anticipated outcomes. Journal of Counseling \& Development. 88(4), 424-431.

Hartaji, D. A. (2012). Motivasi berprestasi pada mahasiswa yang berkuliah dengan jurusan pilihan orangtua. Fakultas Psikologi Universitas Gunadarma.

Hunt, J., \& Eisenberg, D. (2010). Mental health problems and help-seeking behavior among college students. Journal of Adolescent Health, $46(1), 3-10$

Idaiani, S., Suhardi, S., \& Kristanto, A. Y. (2009). Analisis gejala gangguan mental emosional penduduk Indonesia. Journal Kedokteran Indonesia, 59(10), 473-479.

Johnson, T. (2014). Snowball sampling: Introduction. Wiley StatsRef: Statistics Reference Online.

Karin, P. A. E. S. (2017). Gambaran tingkat depresi pada mahasiswa tingkat pertama program studi Ilmu Keperawatan Fakultas Kedokteran Universitas Udayana (laporan penelitian). Universitas Udayana, Bali, Indonesia. Scribbr. https://simdos.unud.ac.id/uploads/file_penelitian_1_dir/730f53e2b7c197cc23053e183efd3704.pdf

Koydemir-Ozden, S. (2014). Self-aspects, perceived social support, gender, and willingness to seek psychological help. International Journal of Mental Health. 39(3), 44-60.

Morgan, C., Mallett, R., Hutchinson, G., Bagalkote, H., Morgan, K., Fearon, P., Dazzan, P., Boydell, J., McKenzie, K., Harrison, G., Murray, R., Jones, P., Craig, T., \& Leff, J. (2005). Pathways to care and ethnicity 2: source of referral and help-seeking. Report from the AESOP study. British Journal of Psychiatry. 186, 290-296.

Ng, T., Jin, A., Ho, R., Chua, H., Fones, C. S. L., \& Lim, L. (2008). Health beliefs and help seeking for depressive and anxiety disorders among urban Singaporean adults. Psychiatric Services. 59, 105-108.

Orji, L. C. \& Abikoye, G. E. (2019). Perceived social support and stress as predictors of help-seeking attitude for mental health among young adults. Department of Psychology, University of Uyo.

Price, M. \& Dalgleish, J. (2013). Help-seeking among indigenous australian adolescents. Youth Studies Australia, 32(1).

Rickwood, D., Deane, F. P., Wilson, C. J., \& Ciarrochi, J. (2005). Young people's help-seeking for mental health problems. Australian eJournal for the Advancement of Mental Health, 4(3).

Russell, D., Cutrona, C. E., Rose, J., \& Yurko, K. (1984). Social and emotional loneliness: An examination of weiss's typology of loneliness. Journal of Personality and Social Psychology, 46(6), 1313.

Salaheddin, K. \& Mason, B. (2016). Identifying barriers to mental health help-seeking among young adults in the UK: A cross-sectional survey. British Journal of General Practice

Satcher, D. (2000). Mental health: A report of the Surgeon General--Executive summary. Professional Psychology: Research and Practice. 31(1), 5-13.

Srivastava, S. \& Angelo, K. M. (2009). Optimism, effects on relationships. Encyclopedia of Human Relationships. $1182-1184$.

Teh, J. L., King, D., Watson, B., \& Liu, S. (2014). Self-stigma, anticipated stigma, and help-seeking communication in people with mental illness. PORTAL Journal of Multidisciplinary International Studies. 11(1). 
Topkaya, N. (2014). Gender, self-stigma, and public stigma in predicting attitudes toward psychological help-seeking. Educational Sciences: Theory \& Practice. 14(2), 480-487.

Verger, P., Guagliardo, V., Gilbert, F., Rouillon, F., \& Kovess-Masfety, V. (2010). Psychiatric disorders in students in six French universities: 12-month prevalence, comorbidity, impairment, and help-seeking. Social Psychiatry and Psychiatric Epidemiology, 45(2), 189-199.

Vidiawati, D., Iskandar, S., \& Agustian, D. (2018). Masalah kesehatan jiwa pada mahasiswa baru di sebuah universitas di Jakarta. EJournal Kedokteran Indonesia, 5(1)

Vogel, D. L., Wade, N. G., Hackler, A. H. (2007). Perceived public stigma and the willingness to seek counseling: The mediating roles of self-stigma and attitudes toward counseling. Journal of Counseling Psychology. 54(1), 40-50.

Young, K. W. (2006). Social support and life satisfaction. International Journal of Psychosocial Rehabilitation, $10(2), 155-164$. 